\title{
DOES THE LOCO-WEED PRODUCE INSANITY? ${ }^{1}$
}

\author{
BY CHARLES W. PILGRIM, M. D., \\ Hudson River State Hospital, Poughkeepsie, N. Y.
}

In the first number of the first volume of Scribner's Magazine Thos. A. Janvier published an exceedingly interesting story entitled, "In Mexico," in which the heroine makes use of a decoction of the "loco-weed" to produce insanity in a faithless lover. In the beautiful language of Janvier: "From before the time of the Spanish Conquest, through all these ages, even until this present day, this plant has been used by Mexican women, when faithlessness in love has bred jealousy, and jealousy, in turn, has bred a longing for revenge. From its flowers and leaves they make a decoction-a little bitter, yet not so bitter but that coffee will disguise it-and who drinks of this decoction surely goes mad. A terrible madness, beginning with failing sight and dizziness, with throbbing pains through all the brain; going on with delirium and strange perversions of sight; with visions which would be laughable but for the dread horror of their cause; with shooting, burning pains in throat and heart; with partial loss of power to breathe, and crushing sense of suffocation. And if the dose is so well gauged that death does not ensue, the pains at last pass away and the end is a violent, or melancholy madness that lasts for months, for years, or through all the remainder of the victim's life. Well have the Spaniards named this hideous plant la flor de muertothe Flower of Death."

This story, which I read in 1887 , was again brought forcibly to my mind about a year ago by the admission into the Hudson River State Hospital of a young man who had been brought from Mexico, suffering from insanity which his friends declared

1 Read before the American Medico-Psychological Association at St. Louis, May 10-13, 1898. 
had been caused by the administration of the "loco-weed." The young man was a civil engineer who, seven months before his admission, had left his home in the State of New York for Mexico where he had secured employment at surveying and engineering work on a coffee plantation in the interior. According to his own statements his life on the plantation was marked by disappointment, excitement and excesses. He and his partner, who was a very dissipated man, were much troubled by lack of funds, due to the dissatisfaction which their work and habits caused their employers, and they were kept in a constant state of excitement by marauding Indians, who were burning houses, killing people and destroying property. To go back a little in the story, which the patient told me during his convalescence, upon his arrival in Mexico he found that the firm by which he had been engaged was fighting other settlers, and especially one whose interests and estate were being looked after by a very unpleasant, drunken, over-bearing American. Disputes in regard to boundary lines were frequent and several fights occurred in which their respective clans took part. These quarrels finally resulted in the stoppage of the work and the natives who had been employed by the patient became dissatisfied and ugly. Failing to receive remittances from his employers he became discouraged, his habits grew worse and finally he became sick and was confined to bed with a low fever. During this time the natives were becoming more and more dissatisfied and threatening, although a few remained friendly to him. In order to understand the line of reasoning adopted by the patient and his friends, it should be remembered that the native Indians have an instinctive hatred for foreigners for having usurped their lands, and are ever ready to wreak vengeance by open violence or secret crime. While he lay sick one of the Indians with whom he had had trouble brought him some food, some of which he ate, although warned not to do so by a friendly native. According to his own statements his mind had been perfectly clear up to this time, but immediately after partaking of the food he became " crazy with thirst," was troubled by illusions and hallucinations, and mistook his own identity, imagining that he was one of the characters in a book which he had been reading. By this time the clamoring of the natives for their pay could no 
longer be quelled, and a violent scene ensued in which revolvers, rifles and knives were used. This of course aggravated the patient's mental condition and his friends realized that they must get him from the interior to the coast where he could receive hospital treatment. He was, therefore, bound to a litter, which was carried by Mexican Indians, and the journey towards the City of Mexico was begun. The carriers found relief during a part of the way by placing the patient upon horseback and again by letting him walk, but the greatest part of the distance was covered as it had been begun. As may well be imagined the journey was full of hardships and dangers. Space forbids recounting the details, but a few incidents may be noted. While resting for the night on one occasion he was bound and placed in a position so near a fire that his feet were blistered. On another occasion he attempted to hang himself to a post with one of the ropes with which he was bound, and nearly succeeded in accomplishing his purpose. But the one incident which is of more interest than any other in showing the trend of the patient's thoughts is his statement that early in their journey they stopped at the ranch of a settler, with whom he had also had trouble, and asked for food. Some was brought by natives, and although one of the carriers whispered to him not to touch it, he partook of it and again became delirious and "crazy with thirst." Finally after many hardships he reached the City of Mexico, weary, foot-sore and unkempt, and was placed in the American Hospital where he was kept until the arrival of his father. Not much is known of his condition and treatment while in this hospital, as a letter addressed by me to the physician in charge received no answer. The patient, however, stated that while there he was kept bound and fastened in bed and though he begged to be allowed to use his hands in eating the privilege was denied him. This statement was corroborated by the father, who also said that they found it necessary to tie the patient in bed while on the steamer in order to frustrate his attempts at escape and suicide. During the five weeks that he was in the American Hospital, his treatment, according to information given by the father, consisted mainly of the iodides of potassium and mercury.

When he came under my observation he was in poor physical 
condition and showed unmistakable signs of secondary syphilis; his pulse was 90; tongue coated and tremulous; pupils dilated; gait feeble; appetite poor; and speech incoherent. He had no correct appreciation of time and mixed up the occurrences of the past few hours with those of months or years back; his ideas of distance were erroneous and he failed to appreciate the difference between a few inches and several feet, on which account he had to be carefully watched in order to prevent him from falling down stairs; he had hallucinations of hearing, talked and muttered to himself in Spanish and was untidy and careless in his habits. The extensor muscles of the left wrist were paralyzed. Under tonic and specific treatment the patient began to improve and at the end of five and one-half months he was discharged recovered.

Such, in brief, is the history, and, while to my own mind, the patient's insanity was due to syphilis, dissipation and climatic influences, his friends remained steadfast in their belief that the "loco-weed" had been given to him in food by the Indians, and they based their belief not only upon the statements of the patient but upon the positive assertion of a native doctor who had at one time treated him.

In order to satisfy myself of the incorrectness of their claim I began to look up the subject, and entered upon an active correspondence with persons who might in any way throw light upon it. The physician of the American Hospital, as stated, failed to reply, as did also a priest whose address had been given to me by a sister of the patient. Several others, however, replied at length, and the salient points are herewith presented:

Mr. Janvier, after my letter had followed him from America to several points in Europe, wrote as follows: "The 'loco-weed" of Northern Mexico is the Datura stramonium of our pharmacopeia; the plant is known also in Southern Mexico together with another 'loco-weed'-mariguana-our Cannabis sativa. Doses less than fatal produce vertigo, headache, dimness of vision or perversion of vision, confusion of thought, sometimes amounting to slight delirium; strange feelings in throat or chest, sometimes a feeling of suffocation, often attended by nausea. A disposition to sleep sometimes, but not always, is induced. Fatal doses produce pain about the heart, excessive thirst, vomiting, strangu- 
lation, anxiety and faintness, partial or complete blindness with dilation of pupil, sometimes swelling of the face, deafness, headache, vertigo, delirium-sometimes of a furious, sometimes of a whimsical character; tremors of the limbs, palsy, and ultimately stupor and convulsions ending in death.

"It is the popular belief (of which I made use in my story, by reference) that a permanent madness can be induced by the ' loco-weed.' Dr. Eduaro Liceagá, the leading physician of the City of Mexico, and the eminent Dr. Elenterio José Gonzales, late of Monterey, have denied this positively. I have known of one case of insanity that was attributed to this weed, but not certainly traced to that cause, in which the madness lasted for three months and was ended by death."

Dr. Isaac Ott, who has investigated the mydriatic and narcotic properties of the "loco-plant" (astragalus mollissimus), said: "Whilst 'loco' produces in horses some cerebral phenomena, I have not seen anything to make me believe it would produce insanity in man."

Dr. Edmond Goldmann, who practiced for several years in Monterey, wrote as follows: "I have had no personal experience with the 'loco-weed' and all I could communicate to you would be from hearsay. The name 'loco-weed' signifies an herb that produces mental disease. In Mexico, however, people attribute this effect not so much to the 'loco-weed,' which is a species of astragalus, as to the stramony leaves and seeds (Datura stramonium). The 'loco-weed' is always dreaded by the stockmen, on account of its baneful effect upon cattle, horses and mules. In Monterey I saw a few cases of insanity which were attributed to the 'loco-plant.' Of course I was skeptical and requested that a sample of the noxious weed be brought to me. It turned out to be stramony in all cases. There are so many causes for insanity in Mexico-to begin with, the prevalence of syphilis to an alarming extent and of such malignancy and stubbornness as I have never seen in any other country, - that one need not look for the causation of a pathological state of the brain to a narcotic like stramony. Malaria and a number of other causes also furnish many cases of brain affection, and thus I may sum up my experience as to the influence of a narcotic like 'loco-weed' or stramony, to have been altogether negative on this point." 
Dr. Mary Gage Day, who has carefully studied the effects of the "loco-plant" (Astragalus mollissimus and Oxytropis Lamberti) upon animals, and who furnished the article upon this subject for Foster's Practical Therapeutics, informed me that she knew of no case of insanity produced by the "loco-weed," but that men who were employed to cut the green weed upon a ranch in Comanche County, Kan., in 1883 , where its effects upon cattle had been particularly baneful, were invariably attacked by nausea, vomiting and sick headache after a few days' work, and that nothing would induce them to continue cutting the weed after these symptoms came on.

Dr. Benavides, who is now practicing in Mexico, wrote that the Aztec Indians use the dried leaves of Stramonium and Cannabis sativa for smoking by mixing them in small quantities with tobacco. He added that when they wish to poison a person they either mix the dried leaves very strongly with tobacco or make a decoction and administer it in some drink. He knew of no case of insanity due to the use of these plants.

Dr. Henry M. Hurd, in a very interesting letter which was published in the Journal of INSANITY for October, I885, called attention to the action of the "loco" or "rattle weed" upon animals and suggested that its physiological and therapeutical actions be studied upon man. He noted the fact that the effects described were due to poisonous doses and suggested the possibility that in physiological doses carefully administered it might prove curative in certain forms of insanity.

A great deal has been written in regard to the effects produced by this plant upon animals and it is well known that "grass-staggers" is produced in those who feed upon it. The prominent symptoms are such as would be due to a loss of muscular co-ordination. They become weak and staggering and a slight blow under the jaw of an affected animal causes him to rear and fall over backward. The brain as well as the cord becomes affected and it is said that the animal acts as if absolutely crazy. He cannot be coaxed or driven and becomes exceedingly dangerous. He loses his shining coat, falls away in flesh, refuses to eat even when food is placed in his mouth, and finally dies of exhaustion. Although tormented by a persistent thirst which impels him to seek water, when it is found 
he does not drink, but lies down in it and frequently drowns in a very shallow stream. Stock-men state that no animal will eat of the weed unless driven to it by hunger, but when it has once been tasted it seems to possess for them the same fatal attraction that opium does for too many human beings and they will then refuse all other forage and wander for miles in search of the plant. While it is well known that Stramonium, Cannabis sativa and kindred plants, produce temporary delirium, and even death when given in excessive doses, and that their long continued use will result in marked mental disturbance, my investigations have convinced me that there is no "loco-weed" which will, in single doses, produce permanent insanity. The contrary belief, however, is so firmly established in the minds of Mexicans that a bill has recently been introduced in the legislature in the State of Queretaro, as I have been informed by Dr. Benavides of San Pedro, forbidding the cultivation of Stramonium and Cannabis sativa on account of the evil uses to which such plants are put by the native Indians. Indeed it is a common belief in Mexico that a decoction of the "loco-weed" was administered to the Empress Carlotta just before her departure to seek assistance from Napoleon, and that it was the cause of her insanity and subsequent seclusion at Miramar. Mme. del Barrio, who accompanied the Empress from Mexico, and who for more than thirty years has been the faithful companion of her lonely life, clings tenaciously to this belief. To the alienist, of course, no such explanation is needed, as her father's death, to whom she was devotedly attached, the loss of the crown, which was more to her than life, and the knowledge of the futility of her efforts to save Maximilian from the fate which later befell him on the "Hill of the Bells," were more than enough to upset even a stronger brain than hers; but the average Mexican brushes aside all such causes as trivial and remains firm in his belief that sometime the secrets of State will show that this dread weed was the sole cause of the hopeless madness of the unhappy Empress. 